\title{
Does Discount Matter in Indonesia e-Wallet Race: A Generation Z e-Wallet Preferences During Pandemics
}

\author{
Arum Prasasti $^{1 *}$; Fatwah Inna Aulisaina ${ }^{2}$; Muhamad Arif Rahman Hakim ${ }^{3}$ \\ ${ }^{1,2,3}$ Department of Management, Faculty of Economics, State University of Malang \\ Jl. Semarang No. 5, Lowokwaru, Malang, Jawa Timur 65145, Indonesia \\ 1arum.prasasti.fe@um.ac.id; ${ }^{2}$ fatwah.inna.1904136@students.um.ac.id; ${ }^{3}$ muhamad.arif.1904136@students.um.ac.id
}

Received: $30^{\text {th }}$ January 2021/ Revised: $05^{\text {th }}$ March 2021/ Accepted: $05^{\text {th }}$ March 2021

\begin{abstract}
How to Cite: Prasasti, A., Aulisaina, F. I., \& Hakim, M. A. R. (2021). Does discount matter in Indonesia e-wallet race: A Generation Z e-wallet preferences during pandemics. The Winners, 22(1), 57-65.

https://doi.org/10.21512/tw.v22i1.7019
\end{abstract}

\begin{abstract}
The research aimed to examine the intention of Generation $\mathrm{Z}$ when using e-wallet for payments and the influence of discounts towards using e-wallet in the time of pandemics. The research applied a qualitative method with total data of 22 students, collected using in-depth interviews through WhatsApp free call. The result shows that discount gives an impact on Generation $\mathrm{Z}$ in choosing the e-wallet, but a long-term loyalty is not guaranteed. The finding demonstrates that there are other influential factors for Generation $\mathrm{Z}$ to choose e-wallet, namely ease of use, interrelated apps with the e-wallet, the security system, and cashless society. The limitations of the research lie in the relatively small numbers of respondents. Due to pandemics with physical distancing requirements, the research only carries out on data collected from 22 students from Economics Faculty in the State University of Malang, Indonesia. However, the research provides an insightful analysis for digital payments industry as a reference. It is expected that fellow researchers and academicians use the research as a fundamental to further investigate digital payments, especially amongst Generation $\mathrm{Z}$ in Indonesia or other parts of the world.
\end{abstract}

Keywords: e-wallet race, consumer preference, Covid-19 pandemic

\section{INTRODUCTION}

In Indonesia, the use of electronic wallet (e-wallet) as a payment method increasingly grows. E-wallet transaction has reached USD 1,5 billion or approximately $\mathrm{Rp} 21$ trillion. The data from Bank Indonesia in 2019 has proven that the digital payment user in Indonesia is exponentially increasing. Whereas e-wallet platform by Indonesian internet-based company has been increasing by $50 \%$ since Q4 in 2017 to Q2 in 2019 (Devita, 2019). The multitude of local financial technology (fintech) companies make Indonesian people choose them as the favourite fintech to use. The data of iPrice and APP Annie show the top five most used e-wallet in Indonesia, namely GoPay, OVO, Dana, LinkAja, and Jenius (Devita, 2019). The e-wallet platform is currently on price war to attract more consumers, especially the Generation Z. The demographic of Indonesian shows that Generation $\mathrm{Z}$ population in the 2030 will be bigger than before (Devita, 2019). Therefore, the e-wallet industry in Indonesia holds a huge potential.

The use of e-wallet cannot be separated from the internet. Internet users in Indonesia are dominated by Millennials which have reached around $40 \%$ of the total population. The current and future Indonesian market is also dominated by Millennials and Generation Z. In 2020, their population will be the largest and will continue to dominate until 2035 (Alvara Strategic Research, 2019). There are 88,66\% of young people who own cell phones. Referring to the survey results in 2019 concerning Indonesian Millennial and Generation Z, 98,2\% of them spend 4-6 hours per day on the internet via smartphone (Alvara Strategic Research, 2019). However, the number Gen $\mathrm{Z}$ using the internet is higher than Millennials by $13 \%$ (Hinduan, Anggraeni, \& Agia, 2020). Gen $\mathrm{Z}$ consumers is expected to increase their per capita spending by more than $70 \%$ in the next five years. Gen $\mathrm{Z}$ and Millennials have a passion for digital media, where e-wallet is one of their digital tools (Bona et al., 2020). There are several factors that influence Millennials to use e-money or cash ("Cashless society", 2019), namely: 1) cash as an unsafe option, 2 ) budgeting and monitoring expenses, 3) speed and convenience, and 4) the availability of discounts and/ or cashback. Regarding Gen Z, 34\% of them globally 
use e-wallet with similar reasons (Jones, 2020).

The country e-wallet platform is now thriving by using discount to attract Gen Z. If one walk up to the high street or shopping mall, they will see many of these e-wallet offering discount or cashback (Putera, 2019). Theoretically, price cut or price promotion is a common marketing tools for business due to its straight forward implementation and promising in a short run (Drechsler et al., 2017). In practice, a consumer can save subsequent amount of money when purchasing a product on discount. Recent evidence suggests that discounts represent the promise that consumers will gain more benefits on their shopping value (Çavuşoğlu, Demirağ, \& Durmaz, 2020). Price reductions are essentially aimed at increasing consumers' interest, product sales and the attractiveness of the product (Janiszewski \& Cunha, 2004).

Price becomes the initial stages before consumer buy a product. This perception of value includes rational consumer evaluations of the cost consumers pay to obtain the product (Çavuşoğlu et al., 2020). In general, if consumers purchase a product at the lowest price, they will gain more benefits from the product (Çavuşoğlu et al., 2020). OVO, GoPay, and many other e-wallets in Indonesia are strengthening the consumers' trust and loyalty by giving discounts on their applications, even more during pandemics (Cicatiello, Secondi, \& Principato, 2019). Those promotional activities are heating up between e-wallet players since the last few years (Putera, 2019).

Catching on the phenomenon of e-wallet race in Indonesia, the research has two research objectives, namely: (1) to examine Gen Z's intention and motive in using e-wallet and (2) to find out the influence of discount for Gen $\mathrm{Z}$ in choosing e-wallet. Previous research have established that Gen $Z$ are technologically savvy. (Roblek et al., 2019; Turner, 2015; Pérez-Escoda, Castro-Zubizarreta, \& FandosIgado, 2016). In addition, the emerging of electronic payment provides multiple benefits such as low risk, convenience, and helping stakeholders in the financial institutions (Dennehy \& Sammon, 2015; Vlasov, 2017; Bezhovski, 2016). However, much of the research has been separately conducted in nature and has not drawn any research towards Gen Z's intention in using e-wallet, and/or how discount influences their decision to use e-wallet. The research attempts to show that Gen Z's choice on e-wallet is influenced by many factors, one of which is discount as the biggest contributor, especially in the time of pandemic. The year of 2020 begins with a virus outbreak in Wuhan, Mainland China that has spread worldwide. The pandemic brought changes to people's livelihood, behaviours, and habits. Therefore, it affects their financial matter. It is believed that one financial problem tends to make people save money by cutting purchases or find products on discount. Considering recent events, the research is commenced. Research has shown that the virus can be transmitted through passing money from one's hand to others', which increases the surge of digital payments amongst people (De' et al., 2020).
The research uses qualitative methods to reveal Gen Z's behaviour in State University of Malang. By employing qualitative modes of inquiry, the research attempts to illustrate how Gen $\mathrm{Z}$ behaves towards e-wallet, and whether discount influences their decision to use e-wallet during pandemics. Data are collected using in-depth-interview through phone call and video call since it is considered one of the best ways to understand consumer behaviour. By understanding the perspective of the largest population in Indonesia, it seems hard to ignore this generation's existence and the critical role they play, especially in this strange and difficult time.

The United States scholar defines Gen $\mathrm{Z}$ in a different classification. Parker and Iglenik (2020) point out that the generation cohort is divided into a few categories, namely: 1) the silent generation (born in 1922-1945), 2) the baby boomers (born in 19461964), 3) Generation X (Gen X) (born in 1965-1980), 4) Millennials (born 1981-1996), and 5) Generation Z (Gen Z) (born 1997-onwards). According to Huang and Cheng (2013), Gen $Z$ is aged between 15-24 years old (born after 1990), currently in their late adolescence and early adulthood. Gen $\mathrm{Z}$ has been labelled as digital natives generation (Huang \& Cheng, 2013; Roblek et al., 2019). Gen Z grows up in the booming period of communication technologies and tends to use various technologies on a daily basis (Casey, 2021). These characteristics coincide with consultancy reports in Malaysia that informed youths (i.e., born around 1997) as Gen-Z who spends a great deal of time using devices such as browsing social media sites and buying products and services via online (Nielsen, 2012). Gen-Z is also endorsed as the I-generation, net-gen and digital natives growing up during the technology explosion (Turner, 2015). This generation's characteristic is education-oriented which holds a great deal of knowledge about new technologies and devices (Nielsen, 2012; PérezEscoda et al., 2016). They are more interested in exploring new technologies, persistence on ease to use devices, and a desire to feel secure and prefer to temporarily escape from realities whenever they encounter challenges (Wood, 2013).

There have been several research on electronic wallet (e-wallet). Kim, Mirusmonov, and Lee (2010) explain that mobile payment (m-payment) is any payment in which a mobile device is used to initiate, authorise and confirm a commercial transaction. The presence of m-payment has manifested multiple benefits to various stakeholders such as financial institutions, mobile network operators, integration partners, merchants, consumers and regulators (Dennehy \& Sammon, 2015). Vlasov (2017) points out that customers would have low risk of losing money by using e-money. In addition, e-money could eliminate tension when stores do not have small change, and customers could easily top up their balance and transfer money amongst their circle (Yeboah-Asiamah et al., 2018). Customers could access transaction records at any time to keep track and manage their 
spending (Baqer et al., 2019). After the growing trend in e-wallet, Baqer et al. (2019) convey that e-wallets competes to add additional values in the form of loyalty cards, special deals and embed cutting-edge technology to enhance customer security.

The intention to use e-wallet has been engaged in several studies. Hill (1977) emphasizes that the high level of usefulness will significantly affect the intention of use. He states that customers try to find the simplest way to make the payment. They tend to compare the previous payment method with the current one to assess the usefulness of each payment method, in order to get simpler payment method (Kim et al., 2010). The intention to use can be someone's behaviour as how they continuously get the value and trust play of the system (Zhou \& Lu, 2011). Digital stuff's ease of use increases the user's awareness that using a particular system is easy to control. It has been considered as the valuable aspect that stimulates the intention to use technology (Venkatesh, 2000; Davis et al., 1989). Innovation interest seems much higher in developing market such as Malaysia, Indonesia, India and Thailand ("Asia Pacific e-commerce", 2020). In addition, the perceived risk of COVID-19 significantly affects customers' intention to use e-wallet. The results show that COVID-19 outbreak has made customers in many countries worry about getting infected by the virus that can possibly be transmitted through physical money (Aji et al., 2020; Ather et al., 2020).

Discount as a promotional tools is largely explored in several previous research. Price cut or price promotion is a common marketing tools for business due to its straight forward implementation and promising in a short run (Drechsler et al., 2017). The research subsequently follows a previous research mentioning that discount cannot guarantee the long term effects of a product purchase (Jedidi et al., 1999). Moreover, Foubert et al. (2018) emphasize that price cuts hold a cost advantage, which is considered more appealing to the consumers. As such, discount is provided by business not only to promote their product but also to retain current consumers (Cicatiello et al., 2019). Ipsos also demonstrates that most first-time e-wallet users are motivated by promotions, hence the phenomenon of e-wallet competition is indeed similar (Agung, 2020).

Consumer preference is regarded in several works of literature. The main factor on influencing consumer preference, satisfaction, and perception is the quality of the product itself (Rust \& Oliver, 2000). Suls \& Wallston (2009) also confirm the benefit of platforms such as ease of use, security, reliance, and efficacy are the most affecting issues about technology control and adoption. The lower grade of these factors could lead the preference and satisfaction to a lower level in adopting digital technology. Most of the consumers have a preference on using the latest technology which makes things more efficient and effective (Lai, 2017). Digital mobile payment provides service for several types of transaction such as bill payment, fund transfer, and shopping. It is believed that consumer will share the experience to their friends, family, and acquaintances when they feel satisfied (Dahlberg et al., 2008). Moreover, consumers use technology continually only if it gives them benefits and fulfils their needs (Karnouskos \& Fokus, 2004).

\section{METHODS}

The research uses interview method to examine the intention of using e-wallet and impact of discount towards user's intention to choose e-wallet product. Interview in qualitative research is one of the most important step in data collection (Prasasti, 2018). Interview has been commonly used in field study and ethnographic research (Qu \& Dumay, 2011). There are numbers of well-known interview types to collect facts such as focus group discussing and indepth interviews (Gubrium et al., 2012). Qualitative research covers the way of asking the limitation of study and specific information that the researchers aim for (Rubin \& Rubin, 2012). Basically, the art of qualitative research lies on the orientation of asking question and interpreting answers. To identify the factors that influence user's intention to choose the e-wallet, the questions focuses on features-discount, comfort, and security - and how big the impact of discount is. The research is supported by the high numbers of Gen $Z$ to do online shopping in various electronic platform.

The high level of consumption in Indonesia compared to another ASEAN country becomes the reason to conduct the research. Such high level of consumptive behaviour is contributed by the presence of e-marketplaces in Indonesia. Most Indonesians choose online shopping rather than offline shopping ("Netizen Indonesia paling gemar", 2019). Therefore, this phenomenon should have an impact on the use of e-wallet in Indonesia. Reports have shown that Indonesian consumers tend to shop online during the pandemic to avoid being exposed to the virus. This is prevalent amongst Gen $\mathrm{Z}$ which is commonly called as post-Millennial. It seems that they likely spend their time and money on online shopping and transactions. This group of informants are selected as the research would like to find out the significant impact on the use of e-wallet in Indonesia (Tashandra, 2018).

Target sample of the research is aimed to the student of economic and business faculty, State University of Malang, class of 2019. COVID-19 pandemic gives impact on how in-depth-interview is carried out. The initial plan is to do face-to-face interview. However, due to the COVID-19 surge, the informants are interviewed via WhatsApp Call as they should stay at home.

The duration of the interview is about 1020 minutes long. The interviews are conducted during October 2020, 8 months into pandemics. The respondents are being approached by selecting several groups of students who have already undertake marketing management class classified into the Gen 
$\mathrm{Z}$ category. The informants selected in this category are assumed that they have already understood the discount concept in marketing. To ensure validity and reliability of the research, the informants' data is analysed by implementing data saturation technique to ensure no new information coming out from all interview results (Hayashi et al., 2019). The interview begins with asking about their consent to record their name and voices until finally, 22 respondents are selected to participate.

The sample of the interview questions are provided: 1) How do you make payments in every online transaction to date in 2020? (QR1); 2) How often do you use e-wallet in your transaction for the last 7 months? (QR2); 3) What makes you choose e-wallet as your payment preference? (QR3); 4) Which one of these e-wallets that you frequently used? (OVO, GoPay, Dana, LinkAja, ShopeePay) (QR4); 5) Which factors that influence you the most for using a specific e-wallet product? Is it discount? (QR5); 6) If there will be no more discount offered, are you going to switch to another e-wallet? (QR6)

The data are analysed using content analysis by tabulating, grouping, and classifying the interview results. Content analysis is defined as a procedure for reviewing the contents of recorded text, allowing the researcher to comprise a larger extent of textual information, and to systematically recognise and classify its properties such as frequencies of the most used key words (Klenke, 2016). In recent years, scholarly awareness in content analysis methods has increased in variation of disciplines involving strategic management, psychology, and being attributed in software equipment (Duriau et al., 2007; Waller \& Fawcett, 2013). In another note, content analysis consents the researcher to create replicable and effective inferences from data to their text (Krippendorff \& Bock, 2009). This kind of text can be defined as book or articles, and also non-text based such as photography, video text, or another communicative medium. Data in the research are analysed based on interview excerpts and supporting literatures using qualitative research software, NVivo, to code and understand essential key findings.

\section{RESULTS AND DISCUSSIONS}

Despite many limitations in conducting faceto-face interviews due to the COVID-19 pandemic, WhatsApp free call is used for the data collection. This does not hindrance the process, yet the interview has been a successful one. The 10-to-20-minute interview comes up with good responses from our informants.

According to the first question (QR1), respondents' answer is in line with previous research that they are choosing electronic wallet for any online payment. From 22 respondents, it is found that they used electronic wallet mostly for payment method. Additionally, the finding shows that there are individuals who use more than one type of electronic wallet. However some respondents indicate that they are still comfortable with conventional payment method. Being indolent for doing top-up and often running out of e-wallet balance are the reasons for them to use cash. Here is the excerpt of conversation:

Interviewer: How do you make payments in every online transaction to date in 2020 ?

Informant: mm, I usually use e-wallet, but it
depends on the situation
(Interview 21 , Khansa)
Informant: I usually make the payment with
cash and m-banking, but for
online transportation I often
use e-wallet (Interview 22,
Mifta)
Informant: It is balance, I do transaction 50\%
using cash and $50 \%$ using
e-wallet. (Interview 8, Nisa)

Following QR2, all respondents have agreed that all of them use e-wallet for making an online payment, yet it is just the intensity of use that sets them apart. Their responses quite diverse from one another. Some of them also give us the comparison in the usage of e-wallet and cash. They state that they often use the e-wallet when certain discount events are given by the platform. Meanwhile others point out they often use e-wallet for online transportation through the application. This result is supported by Agung (2020) that, on average, respondents use e-wallet weekly or 1-2 times per week.

\section{Interviewer: How often do you use e-wallet in your transaction for the last 7 months?}
Informant: I often use e-wallet due to a lot of transaction I have done, perhaps it takes $50 \%$ cash and $50 \%$ e-wallet (Interview 18, Usamah)
Informant: I often use e-wallet, perhaps I use ShopeePay twice a week (Interview 20, Dinda)
Informant: Perhaps, once in a month I use e-wallet (Interview 8, Nisa)
Informant: I use about twice in a week (Interview 7, Namira)

Responding to the third question (QR3), our informants have enthusiastically pointed out the reasons they used e-wallet as their payment method preference. It is explained that there is more than one influential factor to use e-wallet. Few of them states that it would be more uncomplicated. Besides, the interrelated application with the e-wallet also makes them prefer to pay the bill using it. The example of our interview is provided in the excerpt: 
Interviewer: What makes you choose e-wallet as your payment preference?

Informant: Because they (the platform) give
us the ease of use, and
also the security system.
Anyway, the discount given
by the application also
becomes my reason to use
the e-wallet. (Interview 18,
Usamah)

Informant: Cash payment method requires me to go out, while ShopeePay only need to be reloaded. (Interview20, Dinda)

Informant: It's interrelated with the application, so it is easier to be used. (Interview 3, Ifa)

Informant: Because to me, cash is only for paying the unexpected needs. As long as we can top up the balance in our e-wallet. I will use the e-wallet. (Interview 1, Rani)

For QR4, different kinds of response is received. Some of them either use only one product of e-wallet or use more than one kind of e-wallet. From 22 respondents, it is found that 17 respondents use OVO, 12 respondents choose ShopeePay, 9 respondents use GoPay, 5 respondents have LinkAja, and 4 informants choose Dana (see Figure 1). The result demonstrates that OVO is the most used e-wallet amongst them. From the coding reference in NVivo software, 14 of 22 respondents are using OVO. They use either OVO alone or altogether with other e-wallet services. The respondents choose OVO since it hands out discount offers, especially for new users. In addition, OVO provides the complete features, security system, and ease of use for their application. Different reason comes from ShopeePay user as it is the second most used e-wallet. They use ShopeePay to get the extra cashback and free shipping discounts. All OVO users have agreed they will stay with OVO because it maintains giving a lot of benefits even after discount offers are reduced or eliminated. On the other hand, ShopeePay users state that they will leave ShopeePay and go back to using cash when ShopeePay no longer offers cashback and discount purchases.

It shows that discounts are not the only significant factor that influences customer loyalty to use e-wallet in making transactions. The data shows that OVO is the most used e-wallet. The familiarity of the platform and features of OVO have strengthened respondents' loyalty towards OVO as their favourite e-wallet. Therefore, it is considered that ease of use is one of the reasons people choose e-wallet (Dennehy and Sammon, 2015). In this question, the informants actively give their voice and their opinion about e-wallets reflected at the excerpt of interview:
Interviewer: Which one of these products which you use the most? (OVO, GoPay, Dana, LinkAja, ShopeePay)

Informant: I use ShopeePay and OVO, but
ShopeePay that I use the
most (Inteview 9, Indah)
Informant: Mostly I use OVO (Interview 4,
Lurus)
Informant: I use OVO for daily needs (Interview 19, Dewa)

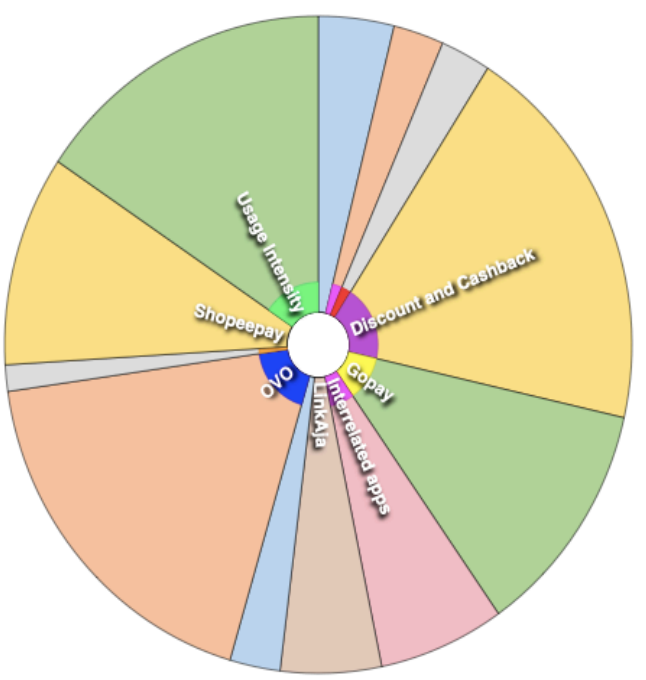

Figure 1 Summary of the OVO Coding Reference Source: Data Analysis, 2020

Regarding QR5, the respondents state that discount is the feature which influence them in choosing the e-wallet product. Here is the excerpt example:

Interviewer: What factors influence you the most for using a specific e-wallet product? Is it discount?

\section{Informant: OVO makes it easy for me to connect with certain merchant products (Interview 1, Rani) \\ Informant: I use e-wallet due to the discount that I got (Interview 8, Nisa) \\ Informant: I got the best security system, lots of discount and also cashback (Interview 13, Lina)}

However, the research finds out that discount is not the only factor that encourage customers to choose e-wallet. The other features includes convenience, interesting user interface design, and the ease of making payment in all places. In addition, most customers use the e-wallet for various needs. This proves that lots of factors can motivate them to consider reasons needed to choose an e wallet. Interestingly, when the excerpts are analysed using NVivo, the coding reference shows that 14 respondents are influenced by discount when 
using an e-wallet product. This result corroborates with the current phenomenon of e-wallet race in Indonesia, as demonstrated in Figure 2.

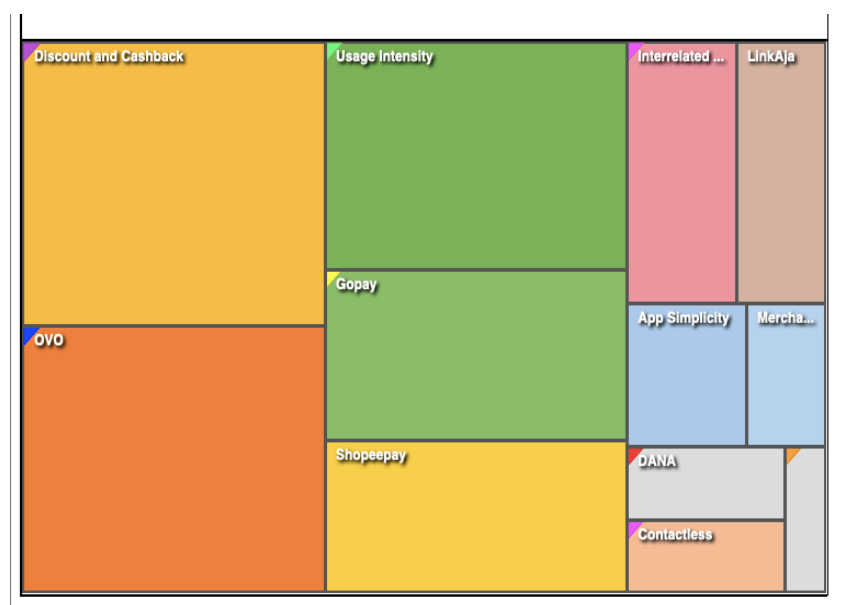

Figure 2 Discount and Cashback Coding Reference Source: Data Analysis, 2020

The sixth question (QR6) is the most confusing part for them to answer. It takes time for them to find out the correct answer. This last question requires a consideration whether they will be loyal to the current e-wallet when there are no more discount. Some respondents state that they will stay loyal with their current e-wallet if they have found it comfortable. Nevertheless, a few people point out that they will not be using the e-wallet if the discount or cashback are no longer available.

\section{Interviewer: If there will be no more discount offered, are you going to switch to another e-wallet?}

Informant: When I got no discount anymore, I will be still using this $e$-wallet. Because the aim of using this is, I got the benefit and comfort (Interview 13, Lina)

Informant: If there is a better feature (discount), why don't we choose that one? (Interview 14, Agitha)

Based on the interview, it is found that the informants frequently use e-wallet for a specific reason such as online transportation. The majority of them mostly use electronic wallet as an online payment method. However, some of them still use cash for daily payment. It is found that the use of e-wallet has different intensity depending on the needs of each respondents. According to the answer, OVO is considered the most popular e-wallet among the other products. This result is in line with the latest research report in Asia Pacific E-commerce and Payment Guide in 2020 mentioning that OVO is the most used e-wallet for online and offline transaction ("Asia Pacific e-commerce", 2020). Research has recorded that the transaction in OVO is already above 1 billion rupiahs. The ease of use, the abundance of benefits, and the interrelating of the application (e.g. OVO-Grab) are the reasons why most of the respondents choose OVO. Moreover, the research finds that discount is the most important feature that e-wallet should have. The finding shows that the respondents will use e-wallet which gives a lot of discount and cashback. Respondents agrees discount is not everything as they could still get benefits although discount is not available. These results reflect those of Ipsos Customer Experience Research which finds that $68 \%$ of Ipsos respondents agrees that convenience is the main reason to keep using e-wallets over cash, while promotion is the second reason, at 23\% (Agung, 2020). E-wallet users have become accustomed to cashless payment as it begins to form part of lifestyle. In addition, promotions does not affect their decisions as much of using e-wallet (Agung, 2020). Figure 3 illustrates the interview results in hierarchy chart on when they appear the most from the informant response.

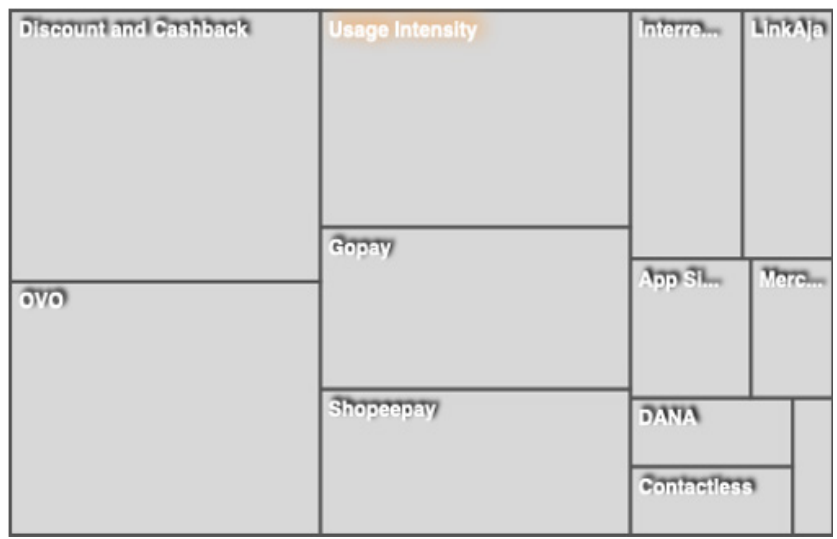

Figure 3 Hierarchy Chart Classification Source: Data Analysis, 2020

Figure 3 provides information on discount and cashback as the most discussed factors by our informants, followed by OVO as the most used e-wallet, and finally usage intensity of their e-wallet choices.

\section{CONCLUSIONS}

The development of e-wallets in 2020 is flourishing. Gen Zs becomes the majority of e-wallet users, so the research offers insight into Gen Z's interest in using e-wallet through in-depth interviews with 22 respondents from Faculty of Economics, State University of Malang, Indonesia. The result does not adequately represent Gen $\mathrm{Z}$ in Indonesia, yet only in a small part of the country. The research finds that all respondents have known and used e-wallet for offline 
and online transaction. Most of them are attracted to use e-wallets due to the discount factor. There are several other reasons for choosing e-wallet such as interrelated application with the e-wallet, applications' ease of use, and the increase of cashless society. The research also shows that OVO and GoPay become the most popular applications despite the expired discounts.

Thus, the research results indicate that discounts are the prevalent factor in choosing e-wallet amongst Gen Z, which can contribute to future research agenda towards Gen Z's e-wallet usage, especially for a literature review in consumer behaviour and preference. However, major limitation lies on our sample size. The data are collected from 22 students from Faculty of Economics in the State University of Malang, Indonesia. Nevertheless, the research provides an insightful analysis for a reference to fellow researchers, academicians, as well as digital payments industry.

The research can also be a basis for further research in digital payments, especially amongst Gen $\mathrm{Z}$ in Indonesia or other part of the world. In future studies, it is recommended to expand the studies into different cultures and geographies. On a side note, the research is carried out during COVID-19 pandemic, in which plenty of people avoid direct contact with things such as paper money, thus e-wallet is preferred for this reason. For future studies, it will be useful to achieve more structured and comprehensive results by conducting research during a different time or expanding the research sample. Therefore the findings of future research might not be similar with the ones in this unprecedented time.

\section{REFERENCES}

Agung, B. (2020). Survei Ipsos soroti tingkat kepuasan pengguna terhadap layanan dompet digital di e-commerce. Daily Social. https://dailysocial. $\mathrm{id} /$ post/survei-ipsos-soroti-tingkat-kepuasanpengguna-terhadap-layanan-dompet-digital-di-ecommerce

Aji, H. M., Berakon, I., Husin, M. M., \& Tan, A. W. K. (2020). COVID-19 and e-wallet usage intention: A multigroup analysis between Indonesia and Malaysia. Cogent Business and Management, 7(1). https://doi.org/10.1080/23311975.2020.1804181.

Alvara Strategic Research. (2019). Behaviors and Preferences of Indonesian Millennial Consumers on E-Commerce Applications in 2019. https://alvarastrategic.com/wp-content/uploads/2019/07/PRESSCON-ENGLISH-E-COMMERCE-REPORT.pdf.

Asia Pacific e-commerce and payments guide. (2020, n.d.). Rapyd. https://www.rapyd.net/resource/asia-pacificecommerce-and-payments-guide/

Ather, A., Patel, B., Ruparel, N. B., Diogenes, A., \& Hargreaves, K. M. (2020). Coronavirus disease 19 (COVID-19): implications for clinical dental care. Journal of Endodontics, 46(5), 584-595. https://doi. org/10.1016/j.joen.2020.03.008.

Baqer, K., Anderson, R., Payne, J. A., Mutegi, L., \& Sevilla, J. (2019). Digitally: Piloting offline payments for phones. Proceedings of the $13^{\text {th }}$ Symposium on Usable Privacy and Security, SOUPS 2017, 131143. https://doi.org/10.17863/CAM.47471.

Bezhovski, Z. (2016). The future of the mobile payment as electronic payment system. European Journal of Business and Management, 8(8), 127-132. https:// core.ac.uk/download/pdf/234627158.pdf.

Bona, C., Koslow, L., Frantz, R., Nadres, B., \& Ratajczak, D. (2020, June 16). How marketers can win with Gen $\mathrm{Z}$ and Millennials post-COVID-19. BCG. https:// www.bcg.com/publications/2020/how-marketerscan-win-with-gen-z-Millennials-post-covid.

Casey, A. E. (2021, January 12). What are the core characteristics of Generation Z? The Annie E. Casey Foundation. https://www.aecf.org/blog/what-arethe-core-characteristics-of-generation-z/

Cashless society, generasi masyarakat tanpa uang tunai. (2019, January). Eastspring Investments. https:// www.eastspring.com/docs/librariesprovider6/ our-perspectives/spring-of-life/2019/spring-oflife---januari-2019---cashless-society-generasimasyarakat-tanpa-uang-tunai.pdf.

Çavuşoğlu, S., Demiră̆, B., \& Durmaz, Y. (2020). Investigation of the effect of hedonic shopping value on discounted product purchasing. Review of International Business and Strategy. https://doi. org/10.1108/RIBS-04-2020-0034.

Cicatiello, C., Secondi, L., \& Principato, L. (2019). Investigating consumers' perception of discounted suboptimal products at retail stores. Resources. https://doi.org/10.3390/resources8030129.

Dahlberg, T., Mallat, N., Ondrus, J., \& Zmijewska, A. (2008). Past, present and future of mobile payments research: A literature review. Electronic Commerce Research and Applications, 7(2), 165-181. https:// doi.org/10.1016/j.elerap.2007.02.001.

Davis, F. D., Bagozzi, R. P., \& Warshaw, P. R. (1989). User Acceptance of Computer Technology: A Comparison of Two Theoretical Models. Management Science, 35(8), 903-1028. https://doi.org/10.1287/ mnsc.35.8.982.

De', R., Pandey, N., \& Pal, A. (2020). Impact of digital surge during Covid-19 pandemic: A viewpoint on research and practice. International Journal of Information Management, $\quad 55 . \quad \mathrm{https} / / /$ doi.org/10.1016/j. ijinfomgt.2020.102171.

Dennehy, D. \& Sammon, D. (2015). Trends in mobile payments research: A literature review. Journal of Innovation Management, 3(1). https://doi. org/10.24840/2183-0606_003.001_0006.

Devita, V. D. (2019). Siapa aplikasi e-wallet dengan pengguna terbanyak di Indonesia. iprice. https:// iprice.co.id/trend/insights/e-wallet-terbaik-diindonesia/

Drechsler, S., Leeflang, P. S. H., Bijmolt, T. H. A., \& Natter, M. (2017). Multi-unit price promotions and their impact on purchase decisions and sales. European Journal of Marketing, 51(5-6), 1049-1074. https:// 
doi.org/10.1108/EJM-12-2013-0729.

Duriau, V. J., Reger, R. K., \& Pfarrer, M. D. (2007). A content analysis of the content analysis literature in organization studies: Research themes, data sources, and methodological refinements. Organizational Research Methods, 10(1), 5-34. https://doi. org/10.1177/1094428106289252.

Foubert, B., Breugelmans, E., Gedenk, K., \& Rolef, C. (2018). Something free or something off? A comparative study of the purchase effects of premiums and price cuts. Journal of Retailing, 94(1), 5-20. https://doi.org/10.1016/j.jretai.2017.11.001.

Gubrium, J., Holstein, J., Marvasti, A. B., \& McKinney, K. D. (2012). The SAGE Handbook of Interview Research: The Complexity of the Craft ( $2^{\text {nd }} \mathrm{Ed}$.). https://doi.org/10.4135/9781412973588.

Hayashi, P., Abib, G., \& Hoppen, N. (2019). Validity in qualitative research: A processual approach. Qualitative Report, 24(1), 98-112. https://nsuworks. nova.edu/tqr/vol24/iss $1 / 8$.

Hill, R. J. (1977). Review of Belief, Attitude, Intention and Behavior: An Introduction to Theory and Research, by M. Fishbein \& I. Ajzen. Contemporary Sociology, 6(2), 244-245. https://doi.org/10.2307/2065853.

Hinduan, Z. R., Anggraeni, A., \& Agia, M. I. (2020). Generation $\mathrm{Z}$ in Indonesia: The self-driven digital. In E. Gentina \& E. Parry (Eds.), The New Generation $Z$ in Asia: Dynamics, Differences, Digitalisation (pp. 121-134). Bingley: Emerald Publishing Limited. https://doi.org/10.1108/978-1-80043-220820201012.

Huang, Y. T. \& Cheng, F. F. (2013). The effect of online sales promotion strategies on consumers' perceived quality and purchase intention: A moderating effect of brand awareness. Proceedings - $20135^{\text {th }}$ International Conference on Service Science and Innovation, ICSSI 2013. https://doi.org/10.1109/ ICSSI.2013.27.

Janiszewski, C. \& Cunha, M. (2004). The influence of price discount framing on the evaluation of a product bundle. Journal of Consumer Research, 30(4), 534546. https://doi.org/10.1086/380287.

Jedidi, K., Mela, C. F., \& Gupta, S. (1999). Managing advertising and promotion for long-run profitability. Marketing Science, 18(1), 1-94. https://doi. org/10.1287/mksc.18.1.1.

Jones, D. (2020, June 8). Following COVID-19: How the virus is affecting the mobile payments industry. Payments Dive. https://www.paymentsdive.com/ ex/mpt/news/following-covid-19-how-the-virus-isaffecting-the-mobile-payments-industry/?

Karnouskos, S. \& Fokus, F. (2004). Mobile payment: A journey through existing procedures and standardization initiatives. IEEE Communications Surveys \& Tutorials, 6(4), 44-66. https://doi. org/10.1109/COMST.2004.5342298.

Kim, C., Mirusmonov, M., \& Lee, I. (2010). An empirical examination of factors influencing the intention to use mobile payment. Computers in Human Behavior, 26(3), 310-322. https://doi.org/10.1016/j. chb.2009.10.013.
Klenke, K. (2016). Content analysis in leadership research. Qualitative Research in the Study of Leadership, 93-122. https://doi.org/10.1108/978-1-78560-651920152006.

Krippendorff, K. \& Bock, M. A. (2009). The Content Analysis Reader. Sage Publications, Inc.

Lai, P. C. (2017). The literature review of technology adoption models and theories for the novelty technology. Journal of Information Systems and Technology Management, 14(1), 21-38. https://doi. org/10.4301/s1807-17752017000100002.

Netizen Indonesia paling gemar belanja online. (2019, February 4). CNN Indonesia. h t t p s : / / w w w . c n n ind o n e s i a . c o m / teknologi/20190201173813-185-365769/netizenindonesia-paling-gemar-belanja-online

Nielsen (2012, August). How digital influences how we shop around the world. The Nielsen Company. https://www.nielsen.com/wp-content/uploads/ sites/3/2019/04/How-Digital-Influences-How-WeShop-Around-the-World.pdf.

Parker, K. \& Iglenik, R. (2020, May 14). On the cusp of adulthood and facing uncertain future: What we know about Gen Z so far. Pew Research Center. https:// www.pewresearch.org/social-trends/2020/05/14/ on-the-cusp-of-adulthood-and-facing-an-uncertainfuture-what-we-know-about-gen-z-so-far-2/

Pérez-Escoda, A., Castro-Zubizarreta, A., \& FandosIgado, M. (2016). Digital skills in the $\mathrm{Z}$ generation: Key questions for a curricular introduction in primary school. Comunicar, 49, 71-79. https://doi. org/10.3916/C49-2016-07.

Prasasti, A. (2018). Analyzing the potential market of local color cosmetics in Indonesia: The case of an Indonesian Small Medium-Enterprise. Proceedings of the $5^{\text {th }}$ International Conference on Community Development (AMCA 2018). https://doi.org/10.2991/ amca-18.2018.137.

Putera, I. (2019, April 15). Indonesia's e-wallet race is heating up. Here are the main players. Finch Capital. https://news.finchcapital.com/post/102fhye/ indonesias-e-wallet-race-is-heating-up-here-are-themain-players

Qu, S. Q. \& Dumay, J. (2011). The qualitative research interview. Qualitative Research in Accounting and Management, 8(3), 238-264. https://doi. org/10.1108/11766091111162070.

Roblek, V., Mesko, M., Dimovski, V., \& Peterlin, J. (2019). Smart technologies as social innovation and complex social issues of the $\mathrm{Z}$ generation. Kybernetes, 48(1), 91-107. https://doi.org/10.1108/K-09-2017-0356.

Rubin, H. \& Rubin, I. (2012). Qualitative Interviewing ( $2^{\text {nd }}$ Ed.): The Art of Hearing Data. California: Sage Publications, Inc. https://doi. org/10.4135/9781452226651.

Rust, R. T. \& Oliver, R. L. (2000). Should we delight the customer? Journal of the Academy of Marketing Science, 28(1), 86-94. https://doi. org/10.1177/0092070300281008.

Suls, J. \& Wallston, K. A. (2009). Social Psychological Foundations of Health and Illness. Wiley-Blackwell. 
https://doi.org/10.1002/9780470753552.

Tashandra, N. (2018, March 22). 80 persen konsumen belanja online orang muda dan wanita. Kompas.com. https://ifestyle.kompas.com/ $\mathrm{read} / 2018 / 03 / 22 / 155001820 / 80$-persen-konsumenbelanja-online-orang-muda-dan-wanita?page=all.

Turner, A. (2015). Generation Z: Technology and social interest. The Journal of Individual Psychology, 71(2), 103-113. https://doi.org/10.1353/jip.2015.0021.

Venkatesh, V. (2000). Determinants of perceived ease of use: Integrating control, intrinsic motivation, and emotion into the technology acceptance model. Information Systems Research, 11(4), 342-365. https://doi.org/10.1287/isre.11.4.342.11872.

Vlasov, A. V. (2017). The evolution of e-money. European Research Studies Journal, 20(1), 215-224. http:// www.ersj.eu/repec/ers/papers/17_1_p21.pdf.

Waller, M. A. \& Fawcett, S. E. (2013). Data science, predictive analytics, and big data: A revolution that will transform supply chain design and management. Journal of Business Logistics, 34(2), 77-84. https:// doi.org/10.1111/jbl.12010.

Wood, S. (2013). Generation Z as consumers: trends and innovation. Institute for Emerging Issues: NC State University, 1-3. https://iei.ncsu.edu/wp-content/ uploads/2013/01/GenZConsumers.pdf.

Yeboah-Asiamah, E., Narteh, B., \& Mahmoud, M. A. (2018). Preventing customer churn in the mobile telecommunication industry: Is mobile money usage the missing link? Journal of African Business, 19(2), 174-194. https://doi.org/10.1080/15228916.2018.14 40462.

Zhou, T. \& Lu, Y. (2011). The effects of personality traits on user acceptance of mobile commerce. International Journal of Human-Computer Interaction, 27(6), 545-561. https://doi.org/10.1080/10447318.2011.55 5298. 